


\section{Nutrient digestibility of processed animal proteins in broilers}

M. M. van Krimpen, P. Bikker and J. van Harn

This research was conducted by Wageningen Livestock Research, commissioned and funded by the European Fat Processors and Renderers Association (EFPRA), and subsidized by the Ministry of Economic Affairs within the framework of the policy supporting research theme 'TKI-AF-BIO' (project number BO-22.04-007-006).

Wageningen Livestock Research

Wageningen, August 2019

Report 1185 
Krimpen, van M.M., P. Bikker and J. van Harn, 2018. Nutrient digestibility of processed animal

proteins in broilers; . Wageningen Livestock Research, Report 1185.

\section{Summary UK}

Processed Animal Proteins (PAPs) have long been banned from farm animal diets in the EU. In this period, raw material selection and processes to prepare PAPs have been improved and diversified allowing for a range of products available for inclusion in animal diets. As a consequence, the products and their respective specifications in present feedstuff tables do not cover the composition and quality of presently available PAPs. This report presents the methods and results of a study, conducted by Wageningen Livestock Research at the request of European Fat Processors and Renderers Association (EFPRA), in which the total tract digestibility of proximate components and ileal phosphorus, calcium and amino acid digestibility of 2 PAPs of pig origin in broiler chickens were evaluated. The results from this study showed that the chemical composition of the new PAPs are broadly similar to the 'former' PAPs, but that the AME and the digestibility of crude fat, crude protein and amino acids of the new PAPs was lower. Therefore it is recommended, once the ban on the use of animal proteins in broiler diets ends, to update the present PAP table figures for broilers.

This report can be downloaded for free at https://doi.org/10.18174/496804 or at www.wur.nl/livestock-research (under Wageningen Livestock Research publications).

\section{(C) 2019 Wageningen Livestock Research}

P.O. Box 338, 6700 AH Wageningen, The Netherlands, T +31 (0)317 483953 ,

E info.livestockresearch@wur.nl, www.wur.nl/livestock-research. Wageningen Livestock Research is part of Wageningen University \& Research.

All rights reserved. No part of this publication may be reproduced and/or made public, whether by print, photocopy, microfilm or any other means, without the prior permission of the publisher or author.

Wageningen Livestock Research is NEN-EN-ISO 9001:2015 certified.

All our research commissions are in line with the Terms and Conditions of the Animal Sciences Group. These are filed with the District Court of Zwolle. 



\section{Table of contents}

$\begin{array}{ll}\text { Foreword } & 5\end{array}$

$\begin{array}{ll}\text { Summary } & 7\end{array}$

1

$\begin{array}{ll}\text { Introduction } & 9\end{array}$

$\begin{array}{lll}1.1 & \text { Background } & 9\end{array}$

1.2 Objective 9

$\begin{array}{lr}\text { Material and Methods } & 10\end{array}$

2.1 Start date and end date of the experiment 10

$\begin{array}{ll}2.2 & \text { Experimental animals } \\ 2.3 & 10\end{array}$

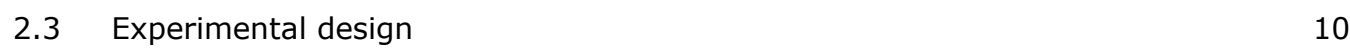

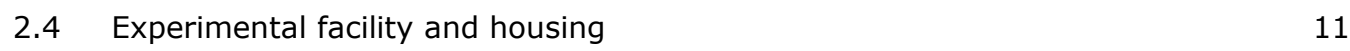

$2.5 \quad$ Experimental diets and feeding $\quad 12$

2.5.1 Test products $\quad 13$

2.6 Measurements 13

$\begin{array}{lll}2.7 & \text { Statistical analysis } & 16\end{array}$

3

$\begin{array}{ll}\text { Results } & 17\end{array}$

$\begin{array}{lll}3.1 & \text { General } & 17\end{array}$

$\begin{array}{lll}3.2 & \text { Diets } & 17\end{array}$

$\begin{array}{lll}3.3 & \text { Performance results } & 18\end{array}$

3.4 Pre-caecal digestibility 19

3.4.1 Nutrient digestibility of experimental diets 19

$\begin{array}{ll}3.4 .2 \text { Nutrient digestibility of PAPs } & 19\end{array}$

$\begin{array}{lll}3.5 & \text { Faecal digestibility } & 20\end{array}$

$\begin{array}{lll}3.6 & \text { Nutritional values new PAPs vs. old PAPs } & 21\end{array}$

$\begin{array}{ll}\text { Conclusions } & 23\end{array}$

$\begin{array}{ll}\text { References } & 24\end{array}$

$\begin{array}{lll}\text { Appendix } 1 & \text { Lay-out experimental room } & 25\end{array}$

Appendix 2 Realised temperature and humidity 26

$\begin{array}{lll}\text { Appendix } 3 & \text { Starter diet (0 - } 14 \text { days) } & 27\end{array}$

Appendix 4 Calculated nutrient content of the PAPs 28

Appendix 5 Experimental diets (14-23 d) 29

Appendix 6 Processing Methods PAPs (EC, 2009) 30

Appendix 7 Analysed nutrient and amino acid contents of diets and PAPs 31 



\section{Foreword}

Processed Animal Proteins (PAPs) have long been banned from farm animal diets in the EU. In this period, raw material selection and processes to prepare PAPs have been improved and diversified allowing for a range of products available for inclusion in animal diets. As a consequence, the products and specifications in present feedstuff tables may not cover the composition and quality of presently available PAPs.

EFPRA (European Fat Processors and Renderers Association) represents the European animal byproduct processing sector. Its objective: to continually improve the safety, security and sustainability of European food production by efficiently processing animal by-products into high valuable fats and proteins. On request of EFPRA, Wageningen Livestock Research performed a study in which the AME and nutrient digestibility of two PAPs of pig origin was investigated in broilers. This report describes the results of this study.

Marinus van Krimpen,

Project leader 


\section{Summary}

Processed Animal Proteins (PAPs) have been banned from farm animal diets in the EU since 2000. In this period, raw material selection and processes to prepare PAPs have been improved and diversified allowing for a range of products available for inclusion in animal diets. As a consequence, the products and specifications in present feedstuff tables may not cover the composition and quality of presently available PAPs. On request of EFPRA (European Fat Processors and Renderers Association) a study with broilers was conducted, in which the AME and the nutrient digestibility of two different PAPs who differed in processing method were studied.

The study was conducted with 234 Ross 308 male broilers from 0 - 23 days of age in a mechanically ventilated room of Research Facility Carus of Wageningen University and Research, Wageningen, The Netherlands. During the first 14 days the birds were housed in six floor pens bedded with white wood shavings (floor space: $1.96 \mathrm{~m}^{2}$ ) and received a starter diet formulated to adequately comply with all nutritional requirements according to CVB. At day 14, 216 healthy and vital animals were selected and equally distributed over 18 floor pens (floor space: $0.98 \mathrm{~m}^{2}$ ). The floor pens contained a flexible slatted floor to avoid intake of excreta and bedding material. From 14 - 23 days, the broilers received one of three experimental diets, representing three treatments (basal diet (BD), BD + PAP1 and BD + PAP2) and 6 replicates (= pens) per treatment. Each pen with 12 birds was randomly assigned to one of the three dietary treatments. Feed and water were ad libitum available during the entire experimental period. The temperature was gradually decreased from $34^{\circ} \mathrm{C}$ on day 0 to $22^{\circ} \mathrm{C}$ at 23 days of age. During the first two days the broilers received continues light, and thereafter till the end of the experiment (= 23 days of age) a day/night lighting schedule of 18 hours light and 6 hour dark (18L:6D) and a light intensity of 20 lux was used.

From days 20 - 23 of the study (3 consecutive days), excreta were collected per pen to determine the metabolize energy (AME) and faecal digestibility of proximate components of the two tested PAPs. At the end of the study (day 23) all broilers were euthanized per pen by an intravenous injection of T61 to determine the pre-caecal (ileal) phosphorus, calcium, and amino acid digestibility of the tested PAPs. In addition to these measurements growth performance results (body weight gain, feed conversion ratio, feed intake, and mortality) were determined from 14 - 23 days.

From this study, in which the total tract digestibility of proximate components and ileal phosphorus, calcium and amino acid digestibility of two PAPs of pig origin in broilers were determined, it can be concluded that:

- No differences were observed in performance objectives between the two tested PAP's.

- Digestibility of crude protein was reduced by $19 \%$ in PAP1 and by $8 \%$ in PAP2, where digestibility of individual amino acids showed similar contrasts compared to CVB (2018).

- Digestibility of crude fat was reduced by $4 \%$ in PAP1 and by $25 \%$ in PAP2, compared to CVB (2018).

- $\mathrm{AME}_{n}$ was reduced by $11.5 \%$ in PAP1 and by $8.2 \%$ in PAP2, compared to CVB (2018).

- Digestibility of Phosphorus was reduced by $9 \%$ in PAP1 and by $19 \%$ in PAP2, compared to CVB (2018).

Since the EU ban in December 2000 on the use of all animal proteins from terrestrials in diets for farm animals, processes to prepare PAPs have been changed. The results from this study showed that the chemical composition of the new PAPs are comparable to the 'former' PAPs, but that the AMEn and the digestibility of crude fat, crude protein and amino acids, and $\mathrm{Ca}$ and $\mathrm{P}$ of the new PAPs were lower compared to the values mentioned in the Dutch CVB Feeding table, based on studies conducted before the ban. Differences in protein digestibility between PAPs may be related to the applied processing methods. Dietary $P$ contents in the current study might not be optimal for determining precaecal $P$ digestibility of the involved PAPs, and more studies are required to validate the observed $\mathrm{P}$ digestibility of the current study. 
It is recommended, once the ban on the use of animal proteins in broiler diets ends, to critically consider the present PAP table values for broilers. 


\section{Introduction}

\subsection{Background}

Processed Animal Protein (PAP) is the collective term for processed products derived from the meat processing industry. Some examples of animal protein are: feather meal, meat and bone meal and blood meal. Animal protein is produced from by-products of animals that have been passed the inspection for human consumption (EFSA, 2011). In general, PAP is a valuable source of energy, protein, minerals and vitamins. Chemical composition, digestibility and nutritional value of different types of PAP varies a lot, depending on the origin, bone content and pressure during heat treatment (Hendriks et al., 2004). Knowledge concerning origin, quality and chemical composition of PAP is essential for appropriate diet optimization.

Since December 2000, PAPs have been banned from farm animal diets in the EU. Since the ban, processes to prepare PAPs have been improved and diversified allowing for a range of products available for inclusion in animal diets. As a consequence, the products and specifications in present feedstuff tables may not cover the composition and quality of presently available PAPs. Moreover, the Dutch CVB updated protocols for nutrient digestibility, while the World Poultry Science Association (WPSA, 2013) developed a new protocol for determination of pre-caecal phosphorus digestibility of feed ingredients in broilers. Hence, up-to-date determination of the composition and nutrient digestibility in pigs and poultry is required as a basis for inclusion in feed tables, especially since reintroduction of PAPs in farm animal diets seems only a matter of time.

On request of EFPRA, Wageningen Livestock Research conducted a digestibility study in which the AME and the nutrient digestibility of two different PAPs in broilers were determined.

\subsection{Objective}

The objective of this study was to determine the total tract digestibility of proximate components and ileal phosphorus, calcium and amino acid digestibility and AME of two different PAPs of pig origin in broilers. 


\section{$2 \quad$ Material and Methods}

\subsection{Start date and end date of the experiment}

Date of arrival broilers (day 0 ):

$27^{\text {th }}$ of June 2017

Date of end experiment (day 23):

$20^{\text {th }}$ of July 2017

The experiment was conducted at the Research Facility Carus of Wageningen University and Research, Wageningen, The Netherlands.

The birds used in the study were treated according to Dutch regulations on animal experiments and animal welfare. The experimental protocol (DEC code: 2017.D0014.003) was approved by the ethical committee of Wageningen UR, Wageningen, The Netherlands on the $19^{\text {th }}$ of June, 2017.

\section{$2.2 \quad$ Experimental animals}

A total of 234 one-day-old male Ross 308 broilers were purchased, of which 216 were allocated to the treatments described below. At the time of arrival at the institute, day-old broilers were weighed and reared during 14 days in six floor pens (approx. $2 \mathrm{~m}^{2} ; 39$ birds/pen, 19.5 birds $/ \mathrm{m}^{2}$ ) bedded with white wood shavings $\left(2 \mathrm{~kg} / \mathrm{m}^{2}\right)$. After two weeks 216 healthy and vital animals were selected and randomly distributed according to a weight class system (12 animals/pen) over 18 floor pens with a flexible slated plastic floor (floor space: $0.98 \mathrm{~m}^{2}$ ).

All broilers were vaccinated at 0 days of age (at the hatchery) with Poulvac IB primer against Infectious Bronchitis (IB) and at 15 days with Nobilis Clone 30 against New Castle Disease (NCD). Day-old broilers were sexed at and delivered by Probroed \& Sloot hatchery, Meppel, The Netherlands.

\subsection{Experimental design}

The faecal digestibility of proximate components and pre-caecal (ileal) phosphorus, calcium and amino acid digestibility of 2 PAPs of pig origin were determined in broilers. The experiment comprised three treatments, one basal diet and two diets in which a part of the basal diet was replaced by one of the PAP's (test products). Each treatment was replicated 6 times. From days $20-23$ of the study (3 consecutive days), excreta were collected per pen to determine the AME and faecal digestibility of proximate components of the two tested PAPs of pig origin. At the end of the study (day 23) all broilers were euthanized per pen by an intravenous injection of T61 to obtain ileal digesta for determining the pre-caecal (ileal) phosphorus, calcium and amino acid digestibility of the tested PAPs of pig origin.

Table 2.1 provides an overview of the experimental design, where Table 2.2 summarizes the allocation of the treatments. In Appendix 1, the lay-out of the experimental room is given.

Table 2.1 Overview of the experimental design.

\begin{tabular}{lr} 
Item & Number \\
Treatments & 3 \\
\hline Broilers per pen & 12 \\
\hline Broilers per treatment & 72 \\
\hline Total number of broilers & 216 \\
\hline Number of blocks & 1 \\
\hline Replicates (pens) per treatment & 6 \\
\hline Total number of pens & 18 \\
\hline
\end{tabular}


Table 2.2 Description of the dietary treatments and allocation of the treatments to pens (days 14 - 23).

\begin{tabular}{llll} 
Groep & Treatment & Number of animals & Location / pen number \\
\hline 1 & Basal diet (BD) & $6 * 12=72$ & $27,30,34,35,38,42$ \\
\hline 2 & BD + PAP1 & $6 * 12=72$ & $26,31,33,37,39,43$ \\
\hline 3 & BD + PAP2 & $6 * 12=72$ & $28,29,32,36,40,41$ \\
\hline
\end{tabular}

\subsection{Experimental facility and housing}

The experiment was conducted in one room at the Research Facility Carus of the Department of Animal Science of Wageningen University, Wageningen, The Netherlands.

Between 0 and 14 days of age (= pre-experimental period), birds were reared in six floor pens $\left(2 \mathrm{~m}^{2}\right)$ bedded with white wood shavings $\left(2 \mathrm{~kg} / \mathrm{m}^{2}\right)$, Figure 2.1 . In each pen 39 birds were housed; stocking density was 19.5 birds per $\mathrm{m}^{2}$. Each pen contained 1 feeding pan (VDL, Valenta, $\varnothing 335 \mathrm{~mm}$ ) and one drinking line with 4 nipple drinkers with drip cups (Impex). During the first three days the feed was also supplied on egg trays.

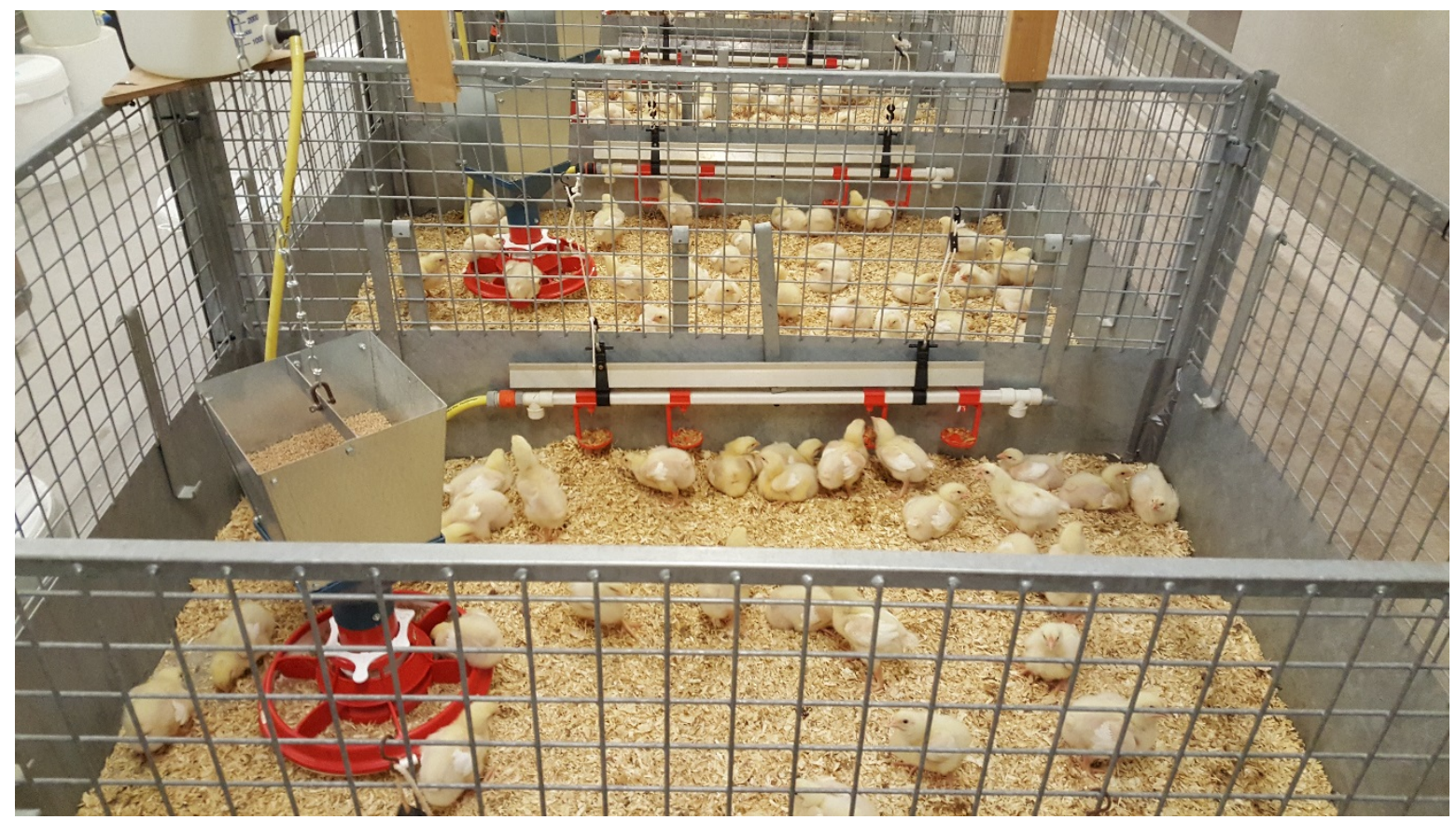

Figure 2.1 Housing of the animals during the pre-experimental period ( 0 - 14 days of age).

On d14, 216 healthy and vital animals were selected and equally distributed (12 birds /pen) over 18 floor pens $\left(1.1 \mathrm{~m} * 0.875 \mathrm{~m}=0.96 \mathrm{~m}^{2}\right)$ with a plastic flexible slatted floor (Figure 2.2). The birds were placed on flexible plastic floors to prevent intake of litter and faeces, which might disturb the nutrient digestibility determination. Distribution of the birds was done in such a way that the difference in average pen weight between the highest and lowest pen weight did not exceed $3 \%$ of the average weight. From d14 onwards, the experimental diets were randomly assigned to the digestibility pens. The diets were supplied for ad libitum intake. Each pen contained a feeding pan (VDL, Valenta, $\varnothing 335 \mathrm{~mm}$ ) and two nipple drinkers with drip cups (Impex). 


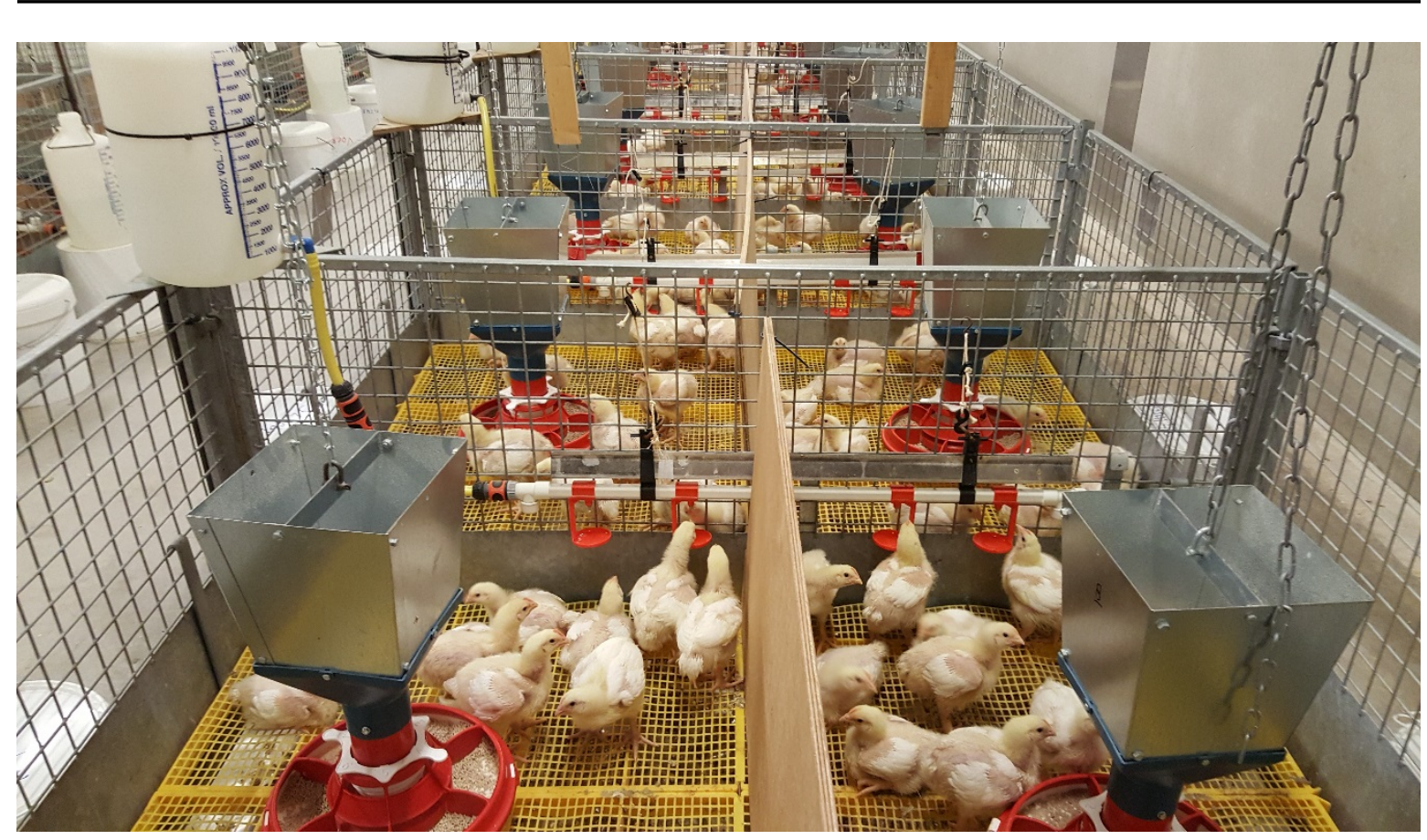

Figure 2.2 Housing of the animals during the experimental period (14 - 23 days of age).

During the first two days the room was continuously illuminated (24L:OD), and thereafter a day/night lighting schedule of 18 hours light and 6 hour dark (18L:6D) was used. The dark period was from 16:00h till 22:00h. Light intensity was 20 lux and ambient temperature was gradually decreased from $34^{\circ} \mathrm{C}$ at arrival till approx. $21^{\circ} \mathrm{C}$ at day 23 according to Table 2.3 . Realised temperature and humidity are presented in Appendix 2.

Table 2.3 Setting temperatures during experiment.

\begin{tabular}{ll} 
Age $(\mathrm{d})$ of the birds & Temperature setting $\left({ }^{\circ} \mathrm{C}\right)$ \\
\hline 0 & 34 \\
\hline 7 & 28 \\
\hline 14 & 25 \\
\hline 21 & 22 \\
\hline 28 & 20 \\
\hline
\end{tabular}

\subsection{Experimental diets and feeding}

During the pre-experimental period (day 0 to 14), broilers were fed a standard starter diet formulated to adequately comply with all nutritional requirements (CVB, 2012, Appendix 3). During the experimental period (between $\mathrm{d} 14$ and 23) the broilers were fed the experimental diets. Feed and water were supplied ad libitum during the entire pre-experimental period. In Table 2.4 an overview of the dietary treatments is given.

\section{Table 2.4 Overview of dietary treatments.}

\begin{tabular}{lll} 
Diet & Description & Basal diet, low in P, Ca and CP \\
\hline 1 & Basal diet (BD) & $82 \%$ basal diet plus $18 \%$ PAP1 \\
\hline 3 & BD + PAP1 & $93 \%$ basal diet plus $7 \%$ PAP2
\end{tabular}

The experimental diets were formulated to meet or exceed the CVB requirements (CVB, 2007) for all nutrients, except for $\mathrm{Ca}$ and $\mathrm{P}$. All diet ingredients were derived of a homogeneous batch. For the formulation of the basal diet, ingredients with a very low $\mathrm{P}$ and phytate content were used. The main components were gelatinised and native maize starch, soybean meal, sugar, oat hulls and egg white powder. Oat hulls were used to ensure adequate fibre content. Titanium dioxide $(5 \mathrm{~g} / \mathrm{kg})$ was used as indigestible marker. 
No actual nutrient digestibility values of the tested PAPs were available when formulating the diets. Therefore, digestible amino acid contents and $\mathrm{AME}_{n}$ values were based on chemical analysis of the PAPs as provided by the EFPRA members and nutrient digestibility coefficients as mentioned in the CVB table (CVB, 2011; PAP from Dutch origin for PAP1, and PAP from foreign origin for PAP2). The calculated nutrient values of the PAPs are provided in Appendix 4.

The experimental diets were obtained by replacing a part of the basal diet (BD) by one of the PAPs. To create diet 2 and 3,18\% and 7\% of the basal diet was replaced by either PAP1 or PAP2, respectively. The calculated (total) P-content and Ca-content of the basal diet were 2.1 and $3.0 \mathrm{~g} / \mathrm{kg}$, respectively. The calculated P-content of test diet 1 and 2 was $4.4 \mathrm{~g} / \mathrm{kg}$ and $5.3 \mathrm{~g} / \mathrm{kg}$, respectively. All diets had a $\mathrm{Ca}: \mathrm{P}$ ratio of $1.4: 1$. The Ca content of the experimental diets was standardized using limestone. No coccidiostats or antimicrobial growth promoters were used in the diets. The test products (PAPs) were delivered by two individual companies, both members of EFPRA. All diets were pelleted ( $2.5 \mathrm{~mm} \mathrm{die})$. In Appendix 5 the composition of all experimental diets is provided. All diets were produced by Research Diet Services, Wijk bij Duurstede, The Netherlands. Starter diet and experimental diets were delivered in $20 \mathrm{~kg}$ bags.

Note: not all required nutrient values of the tested PAPs were available during optimization of the diets. Therefore, feeding table values of two PAPs (one from Dutch origin and one from foreign origin, $C V B, 2007$ ) were used to formulate the diets. The used nutritional feeding table values of the PAPS were based on PAPs before the ban in 2000.

\subsubsection{Test products}

The two processed animal proteins (PAPs) were delivered by two members of EFPRA. The two PAPs differed in chemical composition (Table 2.5 and Appendix 7) as well as in the way they were processed (EC, 2009; see Appendix 6):

1. PAP1 - processing method 1 (pressure sterilisation)

2. PAP2 - processing method 7

Table 2.5 Analysed chemical composition of the tested PAPS.

\begin{tabular}{lcrr} 
& & PAP1 & PAP2 \\
Ash & $\mathrm{g} / \mathrm{kg}$ & 121 & 233 \\
\hline Crude Fibre & $\mathrm{g} / \mathrm{kg}$ & 40 & 16 \\
\hline Dry Matter & $\mathrm{g} / \mathrm{kg}$ & 946 & 948 \\
\hline $\mathrm{N}$ Dumas & $\mathrm{g} / \mathrm{kg}$ & 97 & 96 \\
\hline Crude protein $(6.25 * \mathrm{~N})$ & $\mathrm{g} / \mathrm{kg}$ & 609 & 601 \\
\hline Crude fat & $\mathrm{g} / \mathrm{kg}$ & 144 & 101 \\
\hline Phosphorus & $\mathrm{g} / \mathrm{kg}$ & 19.3 & 41.9 \\
\hline Calcium & $\mathrm{g} / \mathrm{kg}$ & 28.3 & 78.0 \\
\hline
\end{tabular}

\subsection{Measurements}

Diets

Representative samples of all experimental diets were taken during feed production.

In the experimental diets the following analysis were conducted: dry matter (DM), ash, crude protein (CP), crude fat (CFat), crude fibre (CF), starch, sugar, amino acids (AA, 18), calcium (Ca), phosphorus $(\mathrm{P})$ and titanium $(\mathrm{Ti})$. All analyses were done in duplicate and carried out by ANU lab of Wageningen University.

\section{a Performance}

Body weight (BW) of birds per pen was determined at 0,14 and 23 days of age. Cumulative feed intake (FI) per pen was determined from $0-14 d$ (pre-experimental period) and from $14-23 d$ of age (= experimental period) as feed supply from $0-14 d$ and $14-23 d$ minus remaining feed at 14 and 23 days of age, respectively. Body weight gain (BWG) and feed conversion ratio (FCR) of broilers in each pen was calculated from $0-14 \mathrm{~d}$ (pre-experimental period) and $14-23 \mathrm{~d}$ (experimental period). BWG was determined as final BW - initial BW; FCR was calculated as (Total 
FI / (Total BWG + total BWG of dead and culled birds)); FI per animal was calculated as FCR $\mathrm{x}$ BWG. Culling, mortality and health status, including probable causes of any culling, illness or deaths, were recorded daily. In all cases of mortality or culling, the birds were weighed and the date of death was recorded.

- Excreta sampling and analyses

Excreta samples per pen were qualitatively collected once a day from days 20-23 (3 consecutive days) to determine the AME and faecal digestibility of proximate components (DM, ash, crude protein, crude fat, crude fibre and organic matter).

From days 20 - 23 of the study excreta samples per pen were taken daily at 09:00h. The excreta were collected on a plastic collection foil, put underneath the pens at the start (day 20) of the collecting period. Before excreta collection, feathers and feed spillage were carefully removed by air pressure or by hand from the plastic foil to ensure a representative excreta sample. Excreta samples of 3 consecutive days were pooled per pen (18 samples in total) and put in coded plastic bags per pen and immediately after collection stored in a freezer $\left(-20^{\circ} \mathrm{C}\right)$ until further processing at ANU lab (Wageningen, The Netherlands). In preparation for analysis, thawed excreta samples were thoroughly mixed and representative sample of approximately 250 grams was taken and freeze dried. The freeze dried samples were ground $(0.5 \mathrm{~mm})$ and analysed on: DM, ash, crude fat, crude fibre and marker $\left(\mathrm{TiO}_{2}\right)$.

Dissection and sample collection

Approximately 20-30 minutes before euthanasia, the birds were anesthetized by a mixture of Sedamun and Ketamine (5:3) via injection in the breast muscle (dosage $1 \mathrm{ml} / \mathrm{kg} \mathrm{BW}$ ). At 23 of age, all birds were euthanized by an intravenous injection of T61 (an aqueous solution containing per $\mathrm{ml} 200 \mathrm{mg}$ embutramide, $50 \mathrm{mg}$ mebezoniumiodide, and $5 \mathrm{mg}$ tetracainehydrochloride). Subsequently, the chest cavity and the abdomen were opened and the small intestine was ligated and removed from the bird. The content of the terminal part of the ileum, defined as the terminal $1 / 3$ of the ileum (length approx. $15-20 \mathrm{~cm}$ ), was collected from all birds in a cage. The ileal contents (digesta) were collected by gently flushing the gut segment with distilled water into a plastic container. The digesta of all animals were pooled per pen, frozen immediately after collection and stored at $-20^{\circ} \mathrm{C}$ until further analysis. The digesta were collected in the order of cage numbers. Digesta samples were freeze dried and ground $(0.5 \mathrm{~mm})$ and thereafter analysed by ANU lab, Wageningen, The Netherlands prior on: dry matter, nitrogen (Dumas), amino acids (18), calcium, phosphorus and marker $\left(\mathrm{TiO}_{2}\right)$.

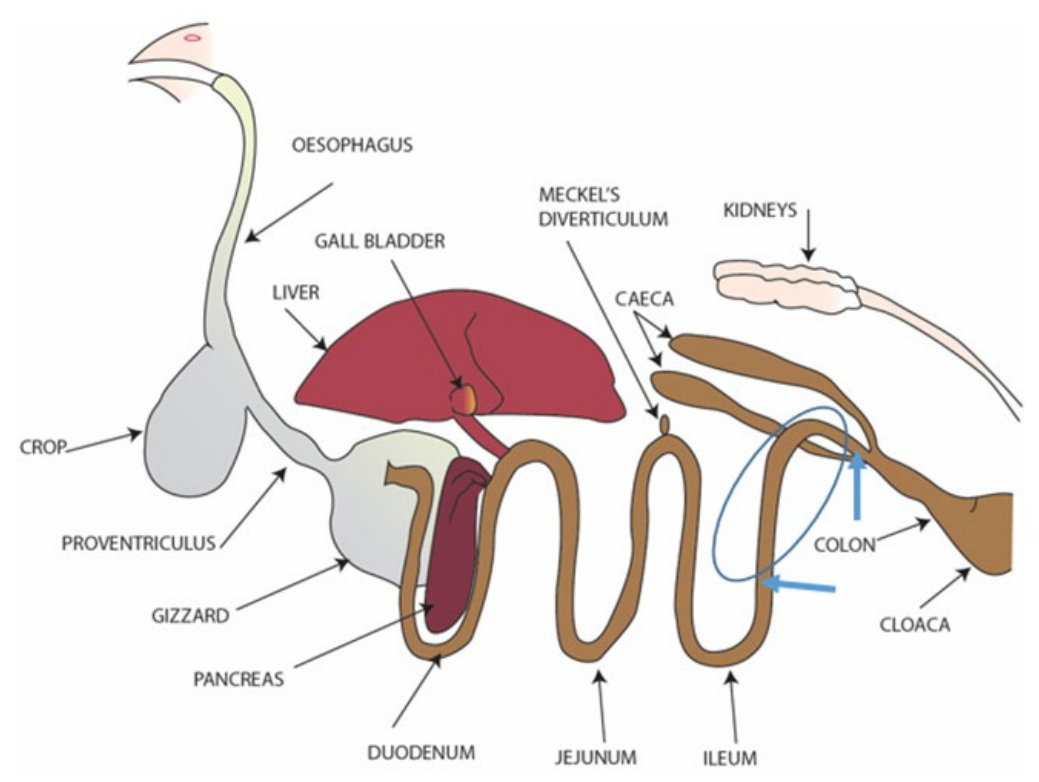

Figure 2.3 Site of collection of the digesta (the terminal part of the ileum, defined as the terminal $1 / 3$ of the ileum) 
Chemical analyses

- Test products (PAPs)

Both PAPs were analysed for dry matter (DM) (ISO 6496, 1998a), crude ash (ISO 5984, 2002), crude fat, crude protein (= N Dumas $* 6.25$ ), crude fibre, calcium (Ca), phosphorus (P) (ISO 11885, 1998b) and amino acids (AA,18).

- Diets

Experimental diets were analysed for DM (ISO 6496, 1998a), crude ash (ISO 5984, 2002), crude fat, crude protein (= NDumas * 6.25), crude fibre, starch, sugar, Ca (ISO 11885, 1998b), P (ISO 11885, 1998b), Amino acids (18) and indigestible marker ( $\left.\mathrm{TiO}_{2}\right)$ (Van Bussel et al., 2010).

- Excreta

Excreta samples were analysed on: DM (ISO 6496, 1998a), crude ash (ISO 5984, 2002), crude fat, crude fibre and indigestible marker $\left(\mathrm{TiO}_{2}\right)$ (Van Bussel et al., 2010).

- Digesta

Ileal digesta of birds from all treatments were analysed for DM (ISO 6496, 1998a), crude protein (= NDumas $* 6.25$ ), amino acids (18), Ca (ISO 11885, 1998b), P (ISO 11885, 1998b), and indigestible marker (TiO2) (Van Bussel et al., 2010)

Based on the analysed content in the experimental diets and excreta the faecal digestibility of DM, ash, organic matter (= DM - ash), crude fat and crude fibre of the diet was calculated using the equation (I).

Based on the analysed content in the experimental diets and digesta the pre-caecal (ileal) $\mathrm{CP}, \mathrm{AA}, \mathrm{Ca}$ and $\mathrm{P}$ digestibility of the diets was calculated (equation I).

Digestibility $(\%)=100-\left[100 \times\left(M_{\text {Diet }} \times\right.\right.$ Nutrient $\left._{\text {Digesta }}\right) /\left(M_{\text {Digesta }} \times\right.$ Nutrient $\left.\left._{\text {Diet }}\right)\right]$

With

- $\quad M_{\text {Diet }}$ and $M_{\text {Digesta }}$ are the analysed concentration of marker $\left(\mathrm{TiO}_{2}\right)$ in diet and digesta $(\mathrm{g} / \mathrm{kg} \mathrm{DM})$

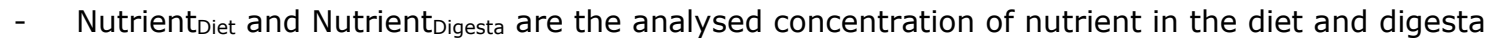
$(\mathrm{g} / \mathrm{kg} \mathrm{DM})$

In addition, the faecal and pre-caecal (ileal) nutrient digestibility of the PAPs were calculated according to the classical method in which the digestible nutrient content of the basal diet is determined and subtracted from the digestible nutrient content in each of the experimental diets with one of the PAPs:

$A=((Y-b) / x) * 100$

With:

$A=$ Nutrient digestibility test product (PAP)

$\mathrm{Y}=$ available nutrient content in the $\operatorname{diet}(\mathrm{g} / \mathrm{kg} \mathrm{DM})$

$x=$ nutrient content originating from test source (PAP) ( $g / k g D M)$

$\mathrm{b}=$ available nutrient in the basal diet

Based on the digestible crude protein and digestible crude fat contents of the PAPs the apparent metabolizable energy (AME) content of the PAPs was calculated using the following quotation (CVB, 2018):

$\operatorname{AME}(M J)=(18.03 * \mathrm{dCP}+38.83 * \mathrm{dCfat}) / 1000$

With:

AME = Apparent Metabolizable Energy in $\mathrm{MJ} / \mathrm{kg}$

$\mathrm{dCP}=$ digestible crude protein in $\mathrm{g} / \mathrm{kg}$

dCfat $=$ digestible crude fat in $\mathrm{g} / \mathrm{kg}$ 


\subsection{Statistical analysis}

Growth performance, and diet digestibility were statistically analysed by ANOVA using GenStat statistical software (Genstat 2015, $18^{\text {th }}$ edition, Release 18.1, VSN International Ltd., Hemel Hempstead, UK), using pen as experimental unit and diet as explanatory factor according to the statistical model:

$Y=\mu+\operatorname{diet}_{i}+e_{i j}$

Where:

$\mathrm{Y} \quad=\quad$ Response parameter

$\mu \quad=\quad$ General mean

diet $\quad=\quad$ Effect of diet $(i=1 \ldots 3)$

e $\quad=\quad$ Error term

AME and nutrient digestibility of the PAPs were statistically analysed by ANOVA using GenStat statistical software (Genstat 2015, $18^{\text {th }}$ edition, Release 18.1, VSN International Ltd., Hemel Hempstead, UK), using pen as experimental unit and the used PAP as explanatory factor according to the statistical model:

$Y=\mu+P A P_{i}+e_{i j}$

Where:

$\mathrm{Y} \quad=\quad$ Response parameter

$\mu \quad=\quad$ General mean

PAP $=$ Effect of PAP $(i=1,2)$

e $\quad=\quad$ Error term

The $P$-value of the treatment effect and the LSD (least signficant differences of the means, $5 \%$ level) were provided per response parameter. Effects with a $P$-value $\leq 0.05$ were considered to be statistically significant. 


\section{Results}

\subsection{General}

The experiment was conducted according to the protocol without major problems or relevant deviations. Day-old broilers arrived healthy, and growth performance results during the preexperimental period ( 0 - 14 days) were in-line (body weight gain) or better (feed conversion ratio) than Ross 308 performance objectives (Table 3.1), indicating that the flock remained healthy during the pre-experimental period. The mean body weight of the male broilers at the start of the experimental period (= day 14 of age) was $478 \mathrm{~g}$. At the end of the experimental period (= day 23) the average weight of the broilers was 1184, which was 61 gram higher compared with the Ross 308 male performance objectives. Also, the average feed conversion ratio was almost 0.08 point lower than the Ross objectives for male broilers, indicating that the flock remained healthy during the experimental period No mortality occurred during the experimental period ( $14-23$ days of age).

Table 3.1 Performance results pre-experimental period ( 0 - 14 days) and on average performance results over the experimental period (14 - 23 days) compared with Ross 308 male performance objectives (Aviagen, 2014).

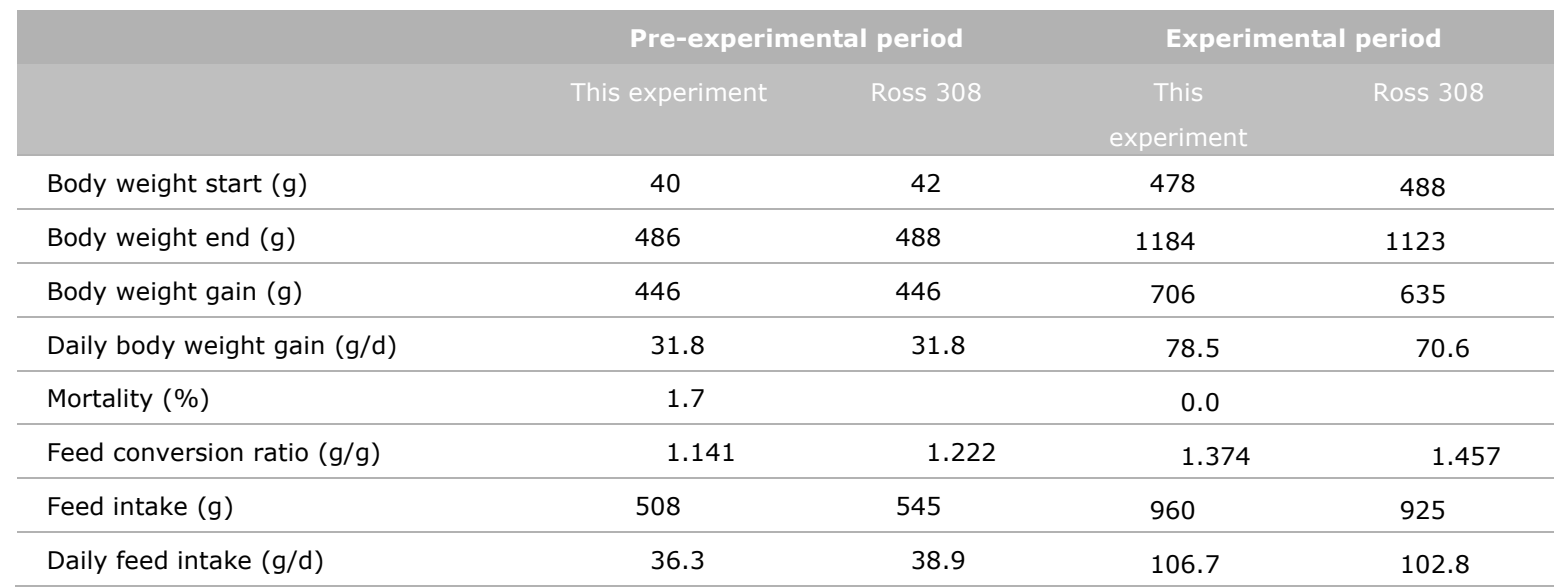

\subsection{Diets}

The calculated and analysed nutrient contents of the experimental diets are presented in Table 3.2, whereas the analysed amino acids contents are given in Appendix 7. The analysed values for dry matter (DM), crude protein (CP), crude ash, starch and sugar were close to the calculated values of the diets. The analysed crude fat was 18,8 and $18 \mathrm{~g} / \mathrm{kg}$ lower than calculated, for diet 1 (Basal diet), $2(B D+P A P 1)$ and $3(B D+P A P 2)$, respectively. The analysed $P$ and $C a$ content of the basal diet were close to the calculated values. The analysed $\mathrm{Ca}$ and $\mathrm{P}$ content of diet 2 (BD+PAP1) were 1.9 and 0.6 $\mathrm{g} / \mathrm{kg}$ higher than calculated, whereas the analysed $\mathrm{Ca}$ and $\mathrm{P}$ content of diet 3 (BD+PAP2) were 0.6 and $0.8 \mathrm{~g} / \mathrm{kg}$ lower than calculated. The titanium content of the experimental diets was on average 0.4 $\mathrm{g} / \mathrm{kg}(=13 \%)$ higher than calculated. 
Table 3.2 Calculated and analysed* nutrient content of experimental diets $(\mathrm{g} / \mathrm{kg})$.

\begin{tabular}{|c|c|c|c|c|c|c|c|}
\hline & & \multicolumn{2}{|c|}{ Basal diet (BD) } & \multicolumn{2}{|c|}{ BD + PAP1 } & \multicolumn{2}{|c|}{$B D+P A P 2$} \\
\hline & & Calc. & Anal. & Calc. & Anal. & Calc. & Anal. \\
\hline Dry matter & $\mathrm{g} / \mathrm{kg}$ & 897 & 886 & 907 & 897 & 902 & 890 \\
\hline Crude protein & $\mathrm{g} / \mathrm{kg}$ & 169 & 170 & 250 & 248 & 203 & 202 \\
\hline Crude ash & $\mathrm{g} / \mathrm{kg}$ & 35 & 31 & 47 & 49 & 43 & 43 \\
\hline Crude fat & $\mathrm{g} / \mathrm{kg}$ & 38 & 20 & 54 & 46 & 43 & 25 \\
\hline Crude fibre & $\mathrm{g} / \mathrm{kg}$ & 34 & 37 & 28 & 35 & 31 & 31 \\
\hline Starch & $\mathrm{g} / \mathrm{kg}$ & 412 & 408 & 340 & 342 & 385 & 388 \\
\hline Sugar & $\mathrm{g} / \mathrm{kg}$ & 122 & 120 & 101 & 101 & 114 & 108 \\
\hline Calcium & $\mathrm{g} / \mathrm{kg}$ & 3.0 & 2.9 & 6.1 & 8.0 & 7.4 & 6.8 \\
\hline Phosphorus & $\mathrm{g} / \mathrm{kg}$ & 2.1 & 2.0 & 4.4 & 5.0 & 5.3 & 4.5 \\
\hline $\mathrm{Ca} / \mathrm{P}$ & & 1.4 & 1.5 & 1.4 & 1.6 & 1.4 & 1.5 \\
\hline Titanium & $\mathrm{g} / \mathrm{kg}$ & 3.0 & 3.4 & 3.0 & 3.4 & 3.0 & 3.4 \\
\hline
\end{tabular}

${ }^{*}$ All values are based on analysis in duplicate

\subsection{Performance results}

Growth performance results during the experimental period are presented in Table 3.3. At the start of the experimental period (at day 14 of age), there were no differences in body weight (BW) between treatment groups. During the experimental period, no significant differences between experimental treatments in body weight (BW), body weight gain (BWG) and feed conversion were observed. Compared to broilers fed the basal diet, broilers that received the PAP2 diet had a higher feed intake (FI). Despite the relatively low Ca and P content of the basal diet, BWG and FCR were not compromised as compared to birds fed the PAP diets.

Table 3.3 Performance results experimental period (14 - 23 days of age).

\begin{tabular}{|c|c|c|c|c|c|}
\hline & $\begin{array}{r}\text { Basal diet } \\
\text { (BD) }\end{array}$ & BD + PAP 1 & BD +PAP2 & F prob & LSD \\
\hline Body weight 14d (g) & 477 & 478 & 478 & 0.915 & 6.9 \\
\hline Body weight 23d (g) & 1206 & 1144 & 1202 & 0.217 & 81.3 \\
\hline Body weight gain $14-23 d(g)$ & 729 & 665 & 724 & 0.206 & 80.6 \\
\hline Mortality $14-23 d(\%)$ & 0.0 & 0.0 & 0.0 & & \\
\hline Feed conversion ratio $14-23 \mathrm{~d}(\mathrm{~g} / \mathrm{g})$ & 1.280 & 1.469 & 1.371 & 0.131 & 0.186 \\
\hline Feed intake $14-23 d(\mathrm{~g})$ & $930^{b}$ & $967^{a b}$ & $984^{a}$ & 0.005 & 30.1 \\
\hline
\end{tabular}

$a, b, c$ Means in the same row without a common superscript differ significantly ( $P \leq 0.05$ ). 


\subsection{Pre-caecal digestibility}

\subsubsection{Nutrient digestibility of experimental diets}

The pre-caecal nutrient and amino acid ( $A A)$ digestibility of the complete diets are presented in Table 3.4. In general the highest $A A$ digestibility, both essential and non-essential $A A$, was achieved with the basal diet. The basal diet + PAP1 (diet 2) had the lowest AA digestibility, whereas the AA-digestibility of BD+PAP2 was in-between.

Table 3.4 Pre-caecal nutrient and amino acid digestibility (in \%) of the experimental diets.

\begin{tabular}{|c|c|c|c|c|c|}
\hline & $\begin{array}{l}\text { Basal diet } \\
\text { (BD) }\end{array}$ & $B D+P A P 1$ & $B D+P A P 2$ & F prob & LSD \\
\hline \multicolumn{6}{|l|}{ Nutrient } \\
\hline Dry matter & $80.0^{a}$ & $76.1^{\mathrm{b}}$ & $79.7^{a}$ & $<.001$ & 0.96 \\
\hline Phosphorus & $78.0^{a}$ & $63.4^{\mathrm{b}}$ & $61.4^{\mathrm{b}}$ & $<.001$ & 3.22 \\
\hline Calcium & $88.1^{a}$ & $60.5^{b}$ & $59.2^{b}$ & $<.001$ & 3.94 \\
\hline Crude protein & $82.2^{\mathrm{a}}$ & $72.6^{c}$ & $79.1^{b}$ & $<.001$ & 2.03 \\
\hline Amino Acids (total) & $84.1^{a}$ & $75.3^{c}$ & $80.8^{b}$ & $<.001$ & 2.17 \\
\hline \multicolumn{6}{|c|}{ Essential amino acids } \\
\hline Lysine & $88.5^{a}$ & $80.5^{c}$ & $84.3^{b}$ & $<.001$ & 1.87 \\
\hline Methionine & $91.5^{a}$ & $84.0^{b}$ & $90.3^{a}$ & $<.001$ & 1.87 \\
\hline Cysteine & $72.2^{a}$ & $67.4^{b}$ & $74.1^{a}$ & $<.001$ & 3.04 \\
\hline Threonine & $77.9^{a}$ & $70.6^{b}$ & $75.5^{a}$ & $<.001$ & 2.90 \\
\hline Tryptophan & $81.2^{a}$ & $71.5^{c}$ & $78.5^{b}$ & $<.001$ & 1.86 \\
\hline Arginine & $90.8^{a}$ & $84.8^{c}$ & $87.1^{b}$ & $<.001$ & 1.71 \\
\hline Valine & $86.6^{a}$ & $79.5^{c}$ & $84.1^{b}$ & $<.001$ & 1.83 \\
\hline Isoleucine & $86.5^{a}$ & $78.7^{c}$ & $83.8^{b}$ & $<.001$ & 1.80 \\
\hline Leucine & $88.1^{a}$ & $81.0^{c}$ & $85.8^{b}$ & $<.001$ & 1.69 \\
\hline Phenylalanine & $88.7^{a}$ & $81.8^{c}$ & $87.0^{b}$ & $<.001$ & 1.54 \\
\hline \multicolumn{6}{|c|}{ Non-essential amino acids } \\
\hline Alanine & $86.2^{a}$ & $78.7^{c}$ & $83.5^{b}$ & $<.001$ & 2.02 \\
\hline Aspartic acid & $81.9^{a}$ & $63.9^{c}$ & $75.2^{b}$ & $<.001$ & 3.04 \\
\hline Glutamic acid & $88.3^{a}$ & $79.1^{c}$ & $84.6^{b}$ & $<.001$ & 1.97 \\
\hline Histidine & 79.1 & 76.0 & 78.5 & 0.073 & 2.84 \\
\hline Proline & $81.8^{a}$ & $73.3^{c}$ & $78.1^{b}$ & $<.001$ & 2.47 \\
\hline Glycine & $93.5^{a}$ & $90.7^{b}$ & $92.5^{a}$ & $<.001$ & 1.11 \\
\hline Serine & $82.4^{a}$ & $71.5^{c}$ & $78.1^{b}$ & $<.001$ & 2.81 \\
\hline Tyrosine & $85.5^{a}$ & $78.7^{c}$ & $83.3^{b}$ & $<.001$ & 1.74 \\
\hline
\end{tabular}

$a, b, c$ Means in the same row without a common superscript differ significantly ( $\leq \leq 0.05)$.

\subsubsection{Nutrient digestibility of PAPs}

PAP2 had a significant higher pre-caecal DM and CP digestibility than PAP1, whereas the P and Ca digestibility of PAP2 was significantly lower. No differences were found in the total AA digestibility. The total pre-caecal AA digestibility did not differ among PAPS. Apparent ileal digestibility of LYS, THR, ILE, ARG, PHE, HIS was not affected by the PAP source (Table 3.5). Apparent ileal digestibility of MET and TRP of PAP2 was significantly higher than of PAP1, whereas CYS and PHE tended to be higher. Determined pre-caecal digestibility of GLY was close or even above $100 \%$, which seemed to be artefacts. 
Table 3.5 Pre-caecal digestibility (in \%) of the tested PAP's.

\begin{tabular}{|c|c|c|c|c|}
\hline Ingredient & PAP1 & PAP2 & F-prob & LSD \\
\hline \multicolumn{5}{|l|}{ Nutrient } \\
\hline Dry matter & $60.9^{b}$ & $76.6^{a}$ & 0.004 & 9.43 \\
\hline Phosphorus & $56.4^{a}$ & $49.9^{b}$ & 0.020 & 5.23 \\
\hline Calcium & $48.8^{a}$ & $40.3^{b}$ & 0.030 & 7.52 \\
\hline Crude protein & $60.9^{b}$ & $68.8^{a}$ & 0.036 & 7.28 \\
\hline Amino Acids (total) & 63.6 & 68.1 & 0.332 & 9.93 \\
\hline \multicolumn{5}{|c|}{ Essential amino acids } \\
\hline Lysine & 71.1 & 69.3 & 0.636 & 8.26 \\
\hline Methionine & $69.5^{b}$ & $83.5^{a}$ & 0.024 & 11.83 \\
\hline Cysteine & 20.6 & 29.3 & 0.067 & 9.47 \\
\hline Threonine & 60.1 & 65.5 & 0.442 & 15.11 \\
\hline Tryptophan & $55.6^{b}$ & $65.5^{a}$ & 0.015 & 7.53 \\
\hline Arginine & 78.0 & 76.2 & 0.577 & 6.81 \\
\hline Valine & 67.9 & 71.1 & 0.454 & 9.04 \\
\hline Isoleucine & 65.8 & 70.8 & 0.263 & 9.50 \\
\hline Leucine & 70.1 & 75.8 & 0.108 & 7.19 \\
\hline Phenylalanine & 69.1 & 77.5 & 0.052 & 8.56 \\
\hline \multicolumn{5}{|c|}{ Non-essential amino acids } \\
\hline Alanine & 71.8 & 75.6 & 0.257 & 6.99 \\
\hline Aspartic acid & 34.4 & 43.3 & 0.283 & 17.51 \\
\hline \multicolumn{5}{|l|}{ Glutamic acid } \\
\hline Histidine & 72.4 & 75.2 & 0.669 & 14.55 \\
\hline Proline & 65.6 & 66.6 & 0.785 & 7.84 \\
\hline Glycine & $96.0^{b}$ & $110.8^{a}$ & $<.001$ & 2.80 \\
\hline Serine & 50.8 & 57.5 & 0.377 & 16.36 \\
\hline Tyrosine & 67.5 & 73.1 & 0.152 & 8.12 \\
\hline
\end{tabular}

$a, b, c$ Means in the same row without a common superscript differ significantly $(P \leq 0.05)$.

\subsection{Faecal digestibility}

Compared with the basal diet, diets supplemented with the PAPs had a lower faecal dry matter (DM), organic matter (OM) and crude fibre (CF) digestibility, but a higher ash digestibility (Table 3.6). Crude fat (Cfat) digestibility of the diet supplemented with PAP2 was lower than the basal diet.

Table 3.6 Faecal digestibility (in \%) of the experimental diets.

\begin{tabular}{|c|c|c|c|c|c|}
\hline & $\begin{array}{l}\text { Basal diet } \\
\text { (BD) }\end{array}$ & $B D+P A P 1$ & $B D+P A P 2$ & F prob & LSD \\
\hline Dry matter & $79.6^{a}$ & $74.5^{c}$ & $78.4^{b}$ & $<.001$ & 0.79 \\
\hline Organic matter & $81.3^{a}$ & $76.3^{c}$ & $80.2^{b}$ & $<.001$ & 0.74 \\
\hline Ash & $34.4^{b}$ & $42.6^{a}$ & $42.5^{a}$ & $<.001$ & 2.18 \\
\hline
\end{tabular}

$a, b, c$ Means in the same row without a common superscript differ significantly ( $P \leq 0.05)$.

PAP2 had a higher faecal dry matter (DM), organic matter (OM), and ash digestibility, but a distinct lower crude fat digestibility compared with PAP1 (Table 3.7). 
Table 3.7 Faecal digestibility (in \%) of the tested PAP's.

\begin{tabular}{lcccc} 
Ingredient & PAP1 & PAP2 & F-prob & LSD \\
Dry matter & $54.5^{\mathrm{b}}$ & $65.6^{\mathrm{a}}$ & 0.008 & 7.45 \\
\hline Organic matter & $55.0^{\mathrm{b}}$ & $67.1^{\mathrm{a}}$ & 0.007 & 7.88 \\
\hline Ash & $42.3^{\mathrm{b}}$ & $52.2^{\mathrm{a}}$ & 0.004 & 6.04 \\
\hline Crude fat & $86.5^{\mathrm{a}}$ & $67.4^{\mathrm{b}}$ & $<.001$ & 5.50 \\
\hline
\end{tabular}

$a, b$ Means in the same row without a common superscript differ significantly $(P \leq 0.05)$.

\subsection{Nutritional values new PAPs vs. old PAPs}

In Tables 3.8 and 3.9 the determined nutritional values (composition) and digestibility coefficients of crude fat, crude protein and amino acids of the two PAPs are compared with the present Dutch Feedstuff Table values (CVB, 2018) of two PAPs, based on studies conducted before the ban.

The chemical composition of the new PAPs is broadly similar to the 'former' PAPs, but the AME and the digestibility of crude fat, crude protein and amino acids of the new PAPs were lower.

On average, the crude protein digestibility of PAP1 was $19 \%$ (60.9\% vs. $75 \%$ ) lower compared with the feeding table values, where the crude protein digestibility of PAP2 was $8 \%$ (68.8 vs. $75 \%$ ) lower. In a study in which seven PAPs were included (Adedokun et al., 2014), pre-caecal protein digestibility coefficients ranged from 65.8 to $78.4 \%$. According to these authors, variation among PAPs was partly affected by processing conditions. PAP1 was processed according to EU processing method 1, while EU processing method 7 has been applied in PAP2. The processing conditions of method 1 are more intensive in terms of heat and pressure as compared to method 7, which may explain the differences in protein digestibility between the two tested PAPs.

The crude fat digestibility of PAP1 was $4 \%$ (86.5 vs. 90\%) lower than the average table value, where for PAP2 it was 25\% (67.4 vs. 90\%) lower. The AMEn value of PAP1 and PAP2 were $11.5 \%$ and $8.2 \%$ below Dutch Feedstuff Table values, respectively. The AME $E_{n}$ value of a tested PAP of pork origin, with a nutrient composition that was comparable to PAP2, amounted 8.9 MJ/kg DM (Bolarinwa et al., 2012). This value is below the determined $A M E_{n}$ value of PAP2, but substantially lower than the value in the CVB table.

The P-digestibility coefficients of PAP1 and PAP2 were $9.5 \%$ and $19.42 \%$ below Dutch Feedstuff Table values, respectively. Although the WPSA protocol (WPSA and Rodehutscord, 2013) for testing the Pdigestibility of animal products was applied, the observed P-digestibility value of PAP2 may be negatively affected by a slightly higher dietary P content than recommended in the protocol (5.3 vs. $4.5 \mathrm{~g} / \mathrm{kg}$ ). Results from New-Zealand (Mutucumarana et al., 2016), however, showed that the precaecal P-digestibility coefficients of four PAPs ranged from 36 to 55\%, indicating that the CVB Table with a precaecal-P digestibility coefficient of $62 \%$ may overestimate the P-digestibility values of current PAPs. A validation study, taking into account that the estimated dietary content for precaecal $P$ of the experimental diets does not exceed birds requirement, has been recommended. 
Table 3.8 Comparison of the analysed nutrient composition, measured digestibility coefficients (\%) of crude protein and crude fat, and apparent metabolizable energy ( $A M E ; M J / k g)$ of the tested PAP's as compared with CVB-table values (2018).

\begin{tabular}{|c|c|c|c|c|c|}
\hline & & PAP 1 & PAP2 & MBM, Dutch & $\begin{array}{l}\text { MBM, foreign, } \\
\text { Cfat }<100 \mathrm{~g} / \mathrm{kg}\end{array}$ \\
\hline Crude Fibre & $\mathrm{g} / \mathrm{kg}$ & 40 & 16 & 28 & 230 \\
\hline Dry Matter & $\mathrm{g} / \mathrm{kg}$ & 946 & 948 & 946 & 940 \\
\hline Crude protein & $\mathrm{g} / \mathrm{kg}$ & 609 & 601 & 581 & 575 \\
\hline Phosphorus & $\mathrm{g} / \mathrm{kg}$ & 19.3 & 41.9 & 22.8 & 34.9 \\
\hline Calcium & $\mathrm{g} / \mathrm{kg}$ & 28.3 & 78.0 & 46.2 & 69.8 \\
\hline Dig. Crude fat & $\%$ & 86.5 & 67.4 & 90.0 & 90.0 \\
\hline $\mathrm{AME}_{\mathrm{n}}$ & $\mathrm{MJ} / \mathrm{kg}$ & 11.5 & 10.1 & 13.0 & 11.0 \\
\hline Dig. phosphorus & $\%$ & 56.4 & 49.9 & 62.3 & 61.9 \\
\hline Dig. Calcium & $\%$ & 48.8 & 40.3 & n.a. & n.a. \\
\hline
\end{tabular}

Table 3.9 Comparison of the precaecal digestibility coefficients of crude protein and amino acids (in $\%$ ) of the tested PAP's as compared with CVB-table values (2007).

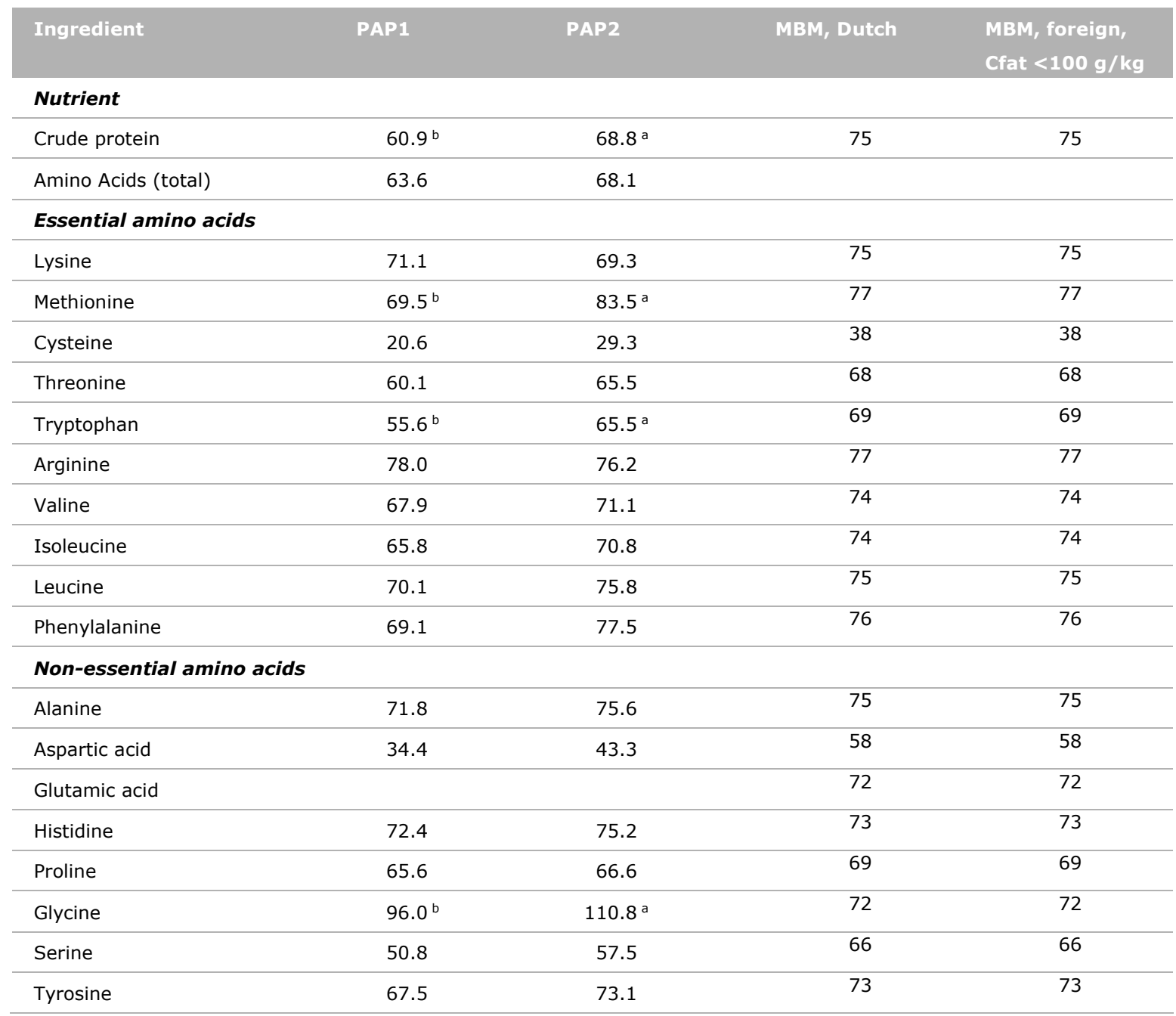




\section{Conclusions}

From this study, in which the total tract digestibility of proximate components and ileal phosphorus, calcium and amino acid digestibility of two PAPs of pig origin in broilers were determined, it can be concluded that:

- No differences were observed in performance objectives between the two tested PAP's.

- Digestibility of crude protein was reduced by $19 \%$ in PAP1 and by $8 \%$ in PAP2, where digestibility of individual amino acids showed similar contrasts compared to CVB (2018).

- Digestibility of crude fat was reduced by $4 \%$ in PAP1 and by $25 \%$ in PAP2, compared to CVB (2018).

- $\mathrm{AME}_{n}$ was reduced by $11.5 \%$ in PAP1 and by $8.2 \%$ in PAP2, compared to CVB (2018).

- Digestibility of Phosphorus was reduced by $9 \%$ in PAP1 and by $19 \%$ in PAP2, compared to CVB (2018).

Since the EU ban in December 2000 on the use of all animal proteins from terrestrials in diets for farm animals, processes to prepare PAPs have been changed. The results from this study showed that the chemical composition of the new PAPs are comparable to the 'former' PAPs, but that the AME $\mathrm{n}_{\mathrm{n}}$ and the digestibility of crude fat, crude protein and amino acids, and $\mathrm{Ca}$ and $\mathrm{P}$ of the new PAPs were lower compared to the values mentioned in the Dutch CVB Feeding table, based on studies conducted before the ban. Differences in protein digestibility between PAPs may be related to the applied processing methods. Dietary $\mathrm{P}$ contents in the current study might not be optimal for determining precaecal $\mathrm{P}$ digestibility of the involved PAPs, and more studies are required to validate the observed $\mathrm{P}$ digestibility of the current study.

It is recommended, once the ban on the use of animal proteins in broiler diets ends, to critically consider the present PAP table values for broilers. 


\section{References}

Aviagen, 2014. Ross 308 Performance objectives 2014.

Bolarinwa, O. A., O. A. Olukosi, and O. Adeola. 2012. Metabolizable energy value of porcine meat and bone meal for broiler chickens. Can. J. Anim. Sci. 92(1):73-78.

CVB, 2007. Feeding Table (Veevoedertabel). Centraal Veevoederbureau, Lelystad, The Netherlands.

CVB, 2012. Tabellenboek Veevoeding 2012, CVB-reeks nr. 50, Den Haag.

CVB, 2018. CVB Veevoedertabel 2018, Editie 2: http://www.cvbdiervoeding.nl/pagina/10081/downloads.aspx

EFSA, 2011. Scientific Opinion on the revision of the quantitative risk assessment (QRA) of the BSE risk posed by processed animal proteins (PAPs). EFSA Journal 2011;9(1):1947.

European Commission, 2009. Regulation (EC) No 1069/2009 of the European Parliament and of the Council of 21 October 2009 laying down health rules as regards animal by-products and derived products not intended for human consumption and repealing Regulation (EC) No 1774/2002 (Animal by-products Regulation).

https://eur-lex.europa.eu/legal-content/EN/TXT/PDF/?uri=CELEX:32009R1069\&rid=9

Genstat, 2014. Reference Manual, Release 18.1. VSN International, Oxford, UK.

Hendriks, W.H., Y.H. Cottam, P.C.H. Morel, and D.V. Thomas, 2004. Source of the variation in meat and bone meal nutritional quality. Asian-Australasian Journal of Animal Sciences 17(1):94-101.

Mutucumarana, R. K., and V. Ravindran. 2016. Measurement of true ileal phosphorus digestibility in meat and bone meal for broiler chickens using the direct method. Anim. Feed Sci. Technol. 219:249-256.

WPSA, and M. Rodehutscord. 2013. Determination of phosphorus availability in poultry. Worlds Poult. Sci. J. 69(3):687-698. 


\section{Appendix 1 Lay-out experimental room}

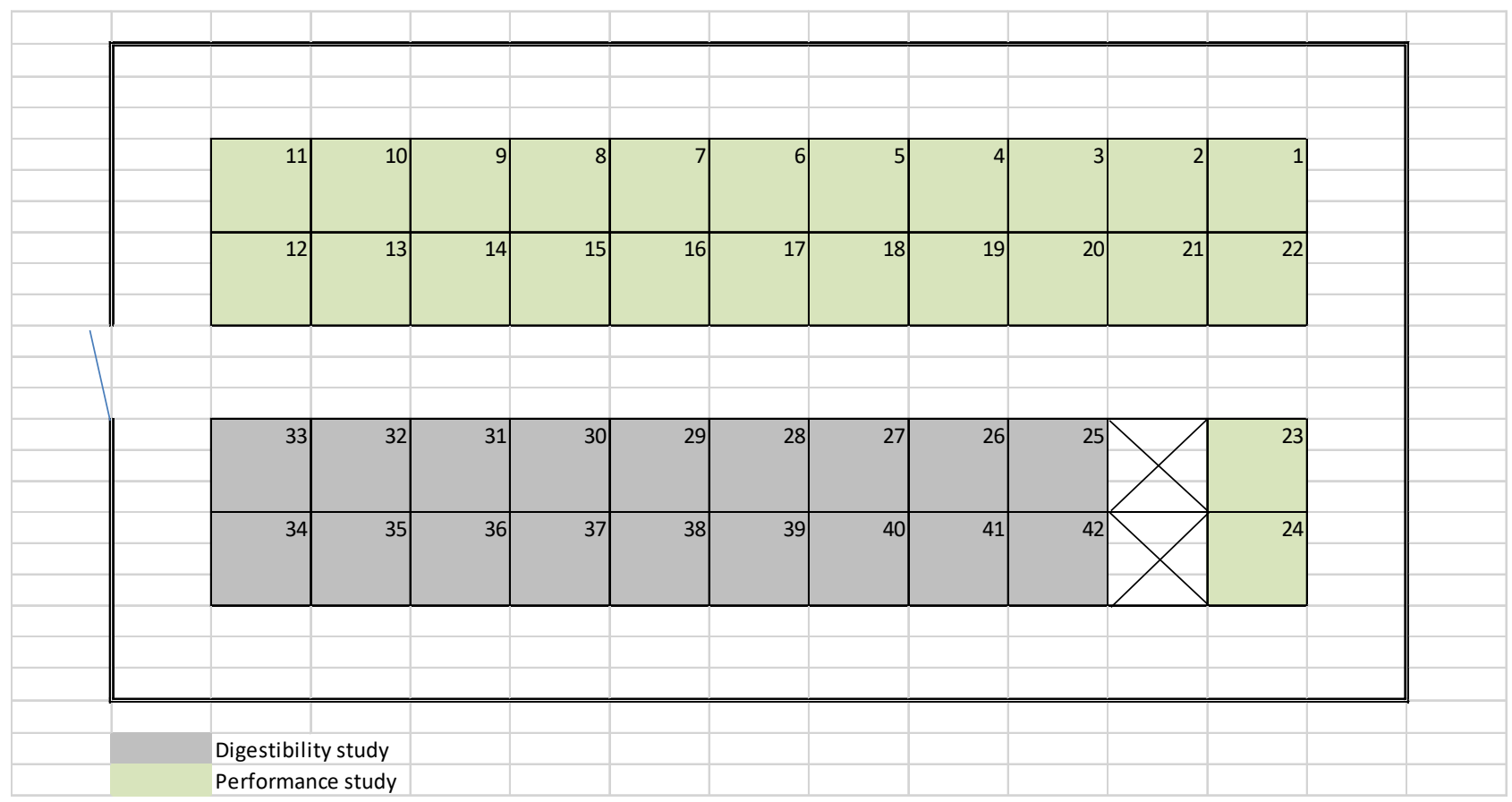




\section{Appendix 2 Realised temperature and humidity}

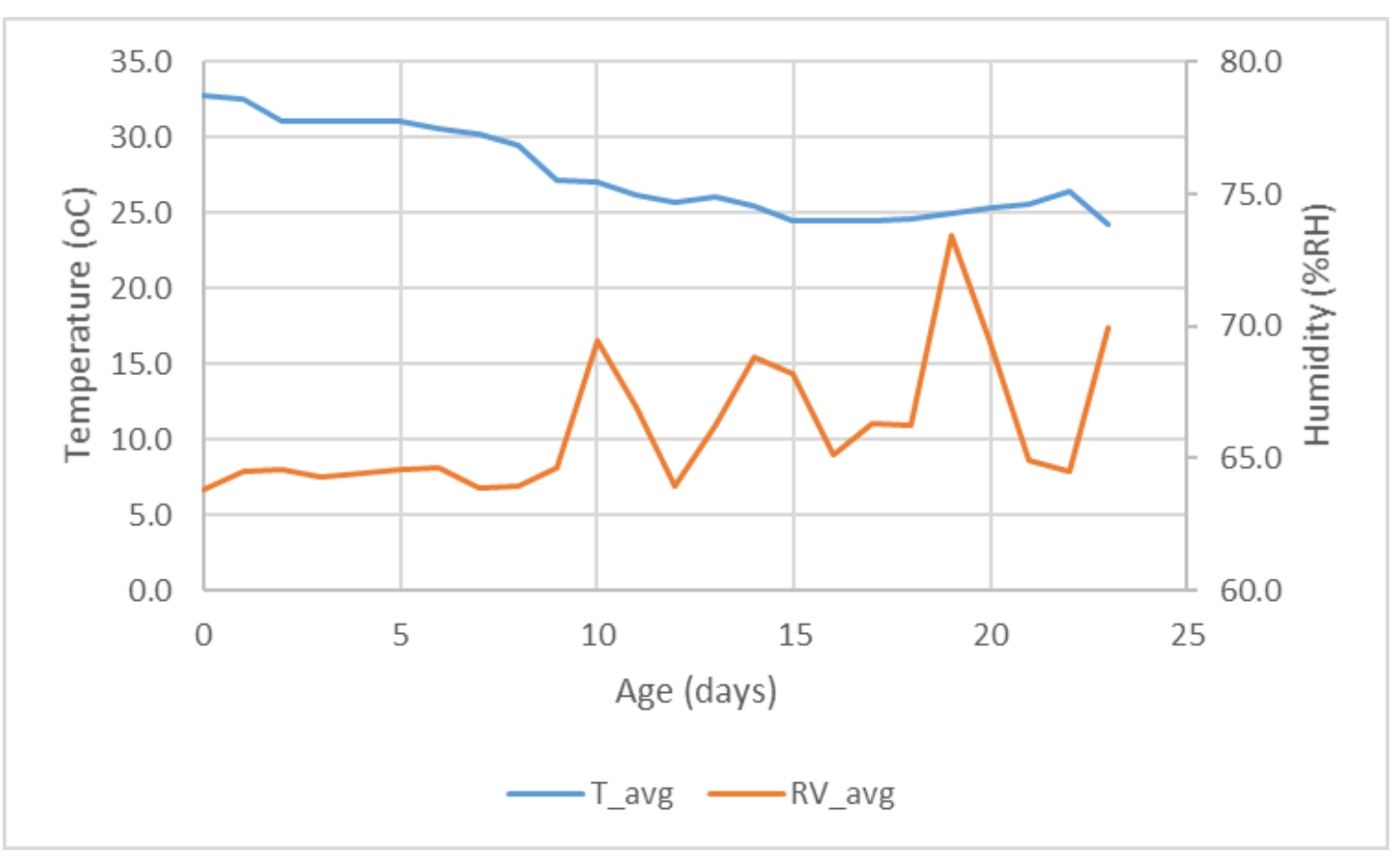




\section{Appendix 3 Starter diet (0 - 14 days)}

\begin{tabular}{|c|c|}
\hline Ingredient & Content (g/kg) \\
\hline Corn & 326.1 \\
\hline Wheat & 250.6 \\
\hline Soybean meal & 330.1 \\
\hline Soybean oil & 36.0 \\
\hline Limestone & 16.0 \\
\hline Monocalcium phosphate & 15.0 \\
\hline Palm oil & 10.0 \\
\hline Premix broilers $^{1}$ & 5.0 \\
\hline Salt & 1.9 \\
\hline Sodium bicarbonate & 2.9 \\
\hline L-Lysine HCL & 2.5 \\
\hline L-Valine & 0.4 \\
\hline DL-Methionine & 3.1 \\
\hline L-Threonine & 1.1 \\
\hline & 1000.0 \\
\hline \multicolumn{2}{|c|}{ Calculated content $(\mathrm{g} / \mathrm{kg})$} \\
\hline$M E_{b r}(M J / k g)$ & 11.91 \\
\hline Crude protein & 214 \\
\hline Crude fat & 66 \\
\hline Crude fibre & 27 \\
\hline Carbohydrates & 502 \\
\hline Ash & 65 \\
\hline Dig. Lysine & 11.6 \\
\hline Dig. Methionine & 5.8 \\
\hline Dig. Methionine+Cystine & 8.7 \\
\hline Dig. Threonine & 7.6 \\
\hline Dig. Tryptophan & 2.2 \\
\hline $\mathrm{Ca}$ & 10.0 \\
\hline $\mathrm{P}$ total & 7.3 \\
\hline $\mathrm{aP}$ & 4.7 \\
\hline $\mathrm{K}$ & 9.2 \\
\hline $\mathrm{Na}$ & 1.6 \\
\hline $\mathrm{Cl}$ & 2.0 \\
\hline $\mathrm{Mg}$ & 1.7 \\
\hline
\end{tabular}

1 Composition of Premix: 12000 IU vitamin A, 2400 IU vitamin D3, 50 IU vitamin E, 1.5 mg vitamin K3, 2 mg vitamin B1, 7.5 mg vitamin B2, 35 $\mathrm{mg}$ niacin amide, $12 \mathrm{mg} \mathrm{d}$-pantothenic acid, $3.5 \mathrm{mg}$ vitamin B6, $25 \mu \mathrm{g}$ vitamin B12, $200 \mu \mathrm{g}$ biotin, $460 \mathrm{mg}$ choline chloride, $1 \mathrm{mg}$ folic acid, 80 $\mathrm{mg} \mathrm{Fe}$ (as FeSO4•7H2O), $85 \mathrm{mg} \mathrm{Mn} \mathrm{(as} \mathrm{MnO),} 12 \mathrm{mg} \mathrm{Cu}$ (as CuSO4•5H2O), $60 \mathrm{mg} \mathrm{Zn} \mathrm{(as} \mathrm{ZnSO4•H2O),} 0.8 \mathrm{mg} \mathrm{I}$ (as KI), $0.15 \mathrm{mg} \mathrm{Se}$ (as $\mathrm{Na} 2 \mathrm{SeO} \cdot 5 \mathrm{H} 2 \mathrm{O}$ ) and $125 \mathrm{mg}$ anti-oxidant. 


\section{Appendix 4 Calculated nutrient content of the PAPs}

\begin{tabular}{|c|c|c|c|}
\hline Nutrient & Unit & PAP1 & PAP2 \\
\hline Dry matter & g & 955.0 & 970.0 \\
\hline Crude Ash & $g$ & 98.0 & 210.0 \\
\hline Crude protein & $\mathrm{g}$ & 621.0 & 620.0 \\
\hline RVETh & $\mathrm{g}$ & 147.0 & 110.0 \\
\hline $\mathrm{Ca}$ & $\mathrm{g}$ & 18.2 & 84.0 \\
\hline $\mathrm{P}$ & g & 14.7 & 46.0 \\
\hline K & $\mathrm{g}$ & 10.5 & 5.1 \\
\hline $\mathrm{Na}$ & $\mathrm{g}$ & 6.5 & 5.0 \\
\hline $\mathrm{Cl}$ & $\mathrm{g}$ & 6.1 & 3.3 \\
\hline AMEn $_{n}$ broiler & MJ & 13.42 & 12.12 \\
\hline LYS & $\mathrm{g}$ & 37.3 & 29.0 \\
\hline MET & $\mathrm{g}$ & 10.6 & 7.0 \\
\hline CYS & $\mathrm{g}$ & 3.7 & 6.0 \\
\hline$M+C$ & $\mathrm{~g}$ & 14.3 & 13.0 \\
\hline TRP & $\mathrm{g}$ & 4.5 & 4.6 \\
\hline Dig. LYSpoultry & $\mathrm{g}$ & 27.2 & 22.6 \\
\hline Dig. METpoultry & $\mathrm{g}$ & 6.6 & 5.5 \\
\hline Dig. CYSpoultry & $\mathrm{g}$ & 4.0 & 4.1 \\
\hline Dig. M+Cpoultry & $\mathrm{g}$ & 10.7 & 9.6 \\
\hline Dig. THRpoultry & $\mathrm{g}$ & 16.2 & 15.9 \\
\hline Dig. TRPpoultry & $\mathrm{g}$ & 3.5 & 3.7 \\
\hline Dig. ILEpoultry & $\mathrm{g}$ & 16.1 & 14.4 \\
\hline Dig. ARGpoultry & $\mathrm{g}$ & 31.6 & 33.0 \\
\hline Dig. PHEpoultry & $g$ & 17.7 & 16.6 \\
\hline Dig. HISpoultry & $\mathrm{g}$ & 10.8 & 7.7 \\
\hline Dig. LEUpoultry & $\mathrm{g}$ & 32.9 & 30.4 \\
\hline Dig. TYRpoultry & $g$ & 11.2 & 14.4 \\
\hline Dig. VALpoultry & $\mathrm{g}$ & 22.8 & 19.5 \\
\hline Dig. ALApoultry & $\mathrm{g}$ & 34.8 & 34.0 \\
\hline Dig. ASPpoultry & $\mathrm{g}$ & 34.2 & 33.8 \\
\hline Dig. GLUpoultry & $g$ & 58.5 & 62.4 \\
\hline Dig. GLYpoultry & $g$ & 49.5 & 56.9 \\
\hline Dig. PROpoultry & $g$ & 32.0 & 33.3 \\
\hline Dig. SERpoultry & $\mathrm{g}$ & 17.3 & 20.1 \\
\hline Retainable P & $g$ & 9.1 & 28.5 \\
\hline Electrolyte balance & $\mathrm{kg}$ & 379 & 255 \\
\hline Ca : retainable $\mathrm{P}$ & & 2.0 & 3.0 \\
\hline
\end{tabular}




\section{Appendix 5 Experimental diets $(14-23 d)$}

\begin{tabular}{|c|c|c|c|c|}
\hline & & Basal diet (BD) & BD + PAP1 & $\mathrm{BD}+\mathrm{PAP2}$ \\
\hline Corn & & 28.98 & 23.85 & 26.99 \\
\hline Maize starch & & 14.00 & 11.53 & 13.04 \\
\hline Maize starch (heat treated) & & 13.50 & 11.11 & 12.57 \\
\hline Soybean meal, $\mathrm{CF}<45, \mathrm{CP}>480$ & & 12.00 & 9.88 & 11.18 \\
\hline Sugar & & 10.00 & 8.23 & 9.31 \\
\hline Egg albumin powder & & 9.57 & 7.88 & 8.92 \\
\hline Oat hulls & & 8.00 & 6.59 & 7.45 \\
\hline Soy oil & & 2.03 & 1.33 & 1.90 \\
\hline Mono calcium phosphate & & 0.14 & 0.12 & 0.13 \\
\hline Calcium carbonate & & 0.55 & 0.56 & 0.15 \\
\hline Premix & & 0.50 & 0.50 & 0.50 \\
\hline Titanium dioxide & & 0.50 & 0.50 & 0.50 \\
\hline Sodium bicarbonate & & 0.13 & 0.00 & 0.00 \\
\hline Magnesium oxide & & 0.10 & 0.10 & 0.10 \\
\hline PAP1 (processing method 1) & & 0.00 & 17.82 & 0.00 \\
\hline PAP2 (processing method 7) & & 0.00 & 0.00 & 7.26 \\
\hline Total & & 100.00 & 100.00 & 100.00 \\
\hline \multicolumn{5}{|l|}{ Nutrients } \\
\hline Dry Matter & $\mathrm{g}$ & 897 & 907 & 902 \\
\hline Crude ash & $\mathrm{g}$ & 35 & 47 & 43 \\
\hline Crude protein & $\mathrm{g}$ & 169 & 250 & 203 \\
\hline Crude Fat & $\mathrm{g}$ & 38 & 54 & 43 \\
\hline Crude fibre & $\mathrm{g}$ & 34 & 28 & 31 \\
\hline Starch & $\mathrm{g}$ & 413 & 340 & 385 \\
\hline Sugar & $\mathrm{g}$ & 122 & 101 & 114 \\
\hline $\mathrm{Ca}$ & $\mathrm{g}$ & 3.0 & 6.1 & 7.4 \\
\hline$P$ & $\mathrm{~g}$ & 2.1 & 4.4 & 5.3 \\
\hline Ca : P & & 1.4 & 1.4 & 1.4 \\
\hline IP & $\mathrm{g}$ & 1.1 & 0.9 & 1.0 \\
\hline $\mathrm{Mg}$ & $\mathrm{g}$ & 1.3 & 1.5 & 1.4 \\
\hline $\mathrm{Na}$ & $\mathrm{g}$ & 1.6 & 2.2 & 1.5 \\
\hline K & $\mathrm{g}$ & 5.2 & 6.1 & 5.2 \\
\hline $\mathrm{Cl}$ & $\mathrm{g}$ & 1.6 & 2.5 & 1.8 \\
\hline LYS & $\mathrm{g}$ & 9.5 & 14.4 & 10.9 \\
\hline MET & $\mathrm{g}$ & 4.2 & 5.4 & 4.4 \\
\hline CYS & $\mathrm{g}$ & 3.5 & 3.6 & 3.7 \\
\hline$M+C$ & $\mathrm{~g}$ & 7.7 & 8.9 & 8.2 \\
\hline THR & $\mathrm{g}$ & 6.8 & 9.4 & 7.8 \\
\hline TRP & $\mathrm{g}$ & 2.2 & 2.6 & 2.4 \\
\hline ILE & $\mathrm{g}$ & 7.8 & 10.3 & 8.6 \\
\hline ARG & $\mathrm{g}$ & 10.1 & 14.9 & 12.2 \\
\hline PHE & $\mathrm{g}$ & 8.8 & 11.1 & 9.8 \\
\hline HIS & $\mathrm{g}$ & 4.2 & 5.8 & 4.6 \\
\hline LEU & $\mathrm{g}$ & 14.1 & 19.1 & 16.0 \\
\hline TYR & $\mathrm{g}$ & 6.2 & 7.7 & 7.1 \\
\hline VAL & $\mathrm{g}$ & 9.4 & 13.2 & 10.7 \\
\hline ALA & $\mathrm{g}$ & 9.2 & 15.4 & 11.5 \\
\hline ASP & $\mathrm{g}$ & 16.6 & 22.1 & 18.7 \\
\hline GLU & $\mathrm{g}$ & 25.2 & 34.9 & 29.1 \\
\hline GLY & $\mathrm{g}$ & 6.4 & 16.4 & 10.8 \\
\hline PRO & $\mathrm{g}$ & 8.2 & 13.9 & 10.7 \\
\hline SER & $\mathrm{g}$ & 9.6 & 12.0 & 10.9 \\
\hline
\end{tabular}




\section{Appendix 6 Processing Methods PAPs (EC, 2009)}

PAP1 - Processing method 1 (pressure sterilisation)

Reduction

1. If the particle size of the animal by-products to be processed is more than 50 millimetres, the animal by-products must be reduced in size using appropriate equipment, set so that the particle size after reduction is no greater than 50 millimetres. The effectiveness of the equipment must be checked daily and its condition recorded. If checks disclose the existence of particles larger than 50 millimetres, the process must be stopped and repairs made before the process is resumed. Time, temperature and pressure

2. The animal by-products with the particle size of no greater than 50 millimetres must be heated to a core temperature of more than $133^{\circ} \mathrm{C}$ for at least 20 minutes without interruption at a pressure (absolute) of at least 3 bars. The pressure must be produced by the evacuation of all air in the sterilisation chamber and the replacement of the air by steam ('saturated steam'); the heat treatment may be applied as the sole process or as a pre- or post-process sterilisation phase.

3. The processing may be carried out in batch or continuous systems.

PAP2 - Processing method 7

1. Any processing method authorised by the competent authority where the following have been demonstrated by the operator to that authority:

(a) the identification of relevant hazards in the starting material, in view of the origin of the material, and of the potential risks in view of the animal health status of the Member State or the area or zone where the method is to be used;

(b) the capacity of the processing method to reduce those hazards to a level which does not pose any significant risks to public and animal health;

(c) the sampling of the final product on a daily basis over a period of 30 production days in compliance with the following microbiological standards:

(i) Samples of material taken directly after the treatment:

Clostridium perfringens absent in $1 \mathrm{~g}$ of the products

(ii) Samples of material taken during or upon withdrawal from storage:

Salmonella: absence in 25g: $n=5, c=0, m=0, M=0$

Enterobacteriaceae: $n=5, c=2 ; m=10 ; M=300$ in $1 \mathrm{~g}$

where:

$\mathrm{n}=$ number of samples to be tested;

$\mathrm{m}=$ threshold value for the number of bacteria; the result is considered satisfactory if the number of bacteria in all samples does not exceed $\mathrm{m}$;

$M=$ maximum value for the number of bacteria; the result is considered unsatisfactory if the number of bacteria in one or more samples is $\mathrm{M}$ or more; and

$c=$ number of samples the bacterial count of which may be between $\mathrm{m}$ and $\mathrm{M}$, the samples still being considered acceptable if the bacterial count of the other samples is $\mathrm{m}$ or less.

2. Details of the critical control points under which each processing plant satisfactorily complies with the microbiological standards must be recorded and maintained so that the operator and the competent authority can monitor the operation of the processing plant. The information to be recorded and monitored must include the particle size, and, as appropriate, the critical temperature, the absolute time, pressure profile, raw material feed rate and fat recycling rate.

3. By way of derogation from point 1 , the competent authority may authorise the use of processing methods which have been approved prior to the date of entry into application of this Regulation, in accordance with Chapter III of Annex V to Regulation (EC) No 1774/2002. L 54/32 Official Journal of the European Union 26.2.2011 EN

4. The competent authority shall permanently or temporarily suspend the application of processing methods referred to in points 1 and 3, if it obtains evidence that any of the circumstances specified in point 1 (a) or (b) have substantially changed.

5. The competent authority shall inform the competent authority of another Member State upon request about the information at its disposal under points 1 and 2 in relation to an authorised processing method. 


\section{Appendix 7 Analysed nutrient and amino acid contents of diets and PAPs}

\begin{tabular}{|c|c|c|c|c|c|c|}
\hline & & Basal diet (BD) & $B D+P A P 1$ & BD + PAP2 & PAP1 & PAP2 \\
\hline \multicolumn{7}{|l|}{ Nutrients } \\
\hline Dry matter & $\mathrm{g} / \mathrm{kg}$ & 886 & 897 & 890 & 946 & 948 \\
\hline Crude protein & $\mathrm{g} / \mathrm{kg}$ & 170 & 248 & 202 & 609 & 601 \\
\hline Crude ash & $\mathrm{g} / \mathrm{kg}$ & 31 & 49 & 43 & 121 & 233 \\
\hline Crude fat & $\mathrm{g} / \mathrm{kg}$ & 20 & 46 & 25 & 144 & 101 \\
\hline Crude fibre & $\mathrm{g} / \mathrm{kg}$ & 37 & 35 & 31 & 40 & 16 \\
\hline Starch & $\mathrm{g} / \mathrm{kg}$ & 408 & 342 & 388 & -- & -- \\
\hline Sugar & $\mathrm{g} / \mathrm{kg}$ & 120 & 101 & 108 & -- & -- \\
\hline Calcium & $\mathrm{g} / \mathrm{kg}$ & 2.9 & 8.0 & 6.8 & 28.3 & 78 \\
\hline Phosphorus & $\mathrm{g} / \mathrm{kg}$ & 2.0 & 5.0 & 4.5 & 19.3 & 41.9 \\
\hline $\mathrm{Ca} / \mathrm{P}$ & & 1.5 & 1.6 & 1.5 & 1.5 & 1.9 \\
\hline Titanium & $\mathrm{g} / \mathrm{kg}$ & 3.4 & 3.4 & 3.4 & -- & -- \\
\hline \multicolumn{7}{|l|}{ Amino acids } \\
\hline TRP & $\mathrm{g} / \mathrm{kg}$ & 2.3 & 3.0 & 2.5 & 5.8 & 4.7 \\
\hline ASP & $\mathrm{g} / \mathrm{kg}$ & 17.8 & 23.1 & 19.7 & 44.8 & 43.0 \\
\hline THR & $\mathrm{g} / \mathrm{kg}$ & 7.2 & 9.8 & 8.1 & 20.7 & 20.1 \\
\hline SER & $\mathrm{g} / \mathrm{kg}$ & 9.3 & 11.4 & 10.3 & 22.2 & 25.7 \\
\hline GLU & $\mathrm{g} / \mathrm{kg}$ & 27.2 & 35.2 & 30.5 & 69.8 & 74.4 \\
\hline PRO & $\mathrm{g} / \mathrm{kg}$ & 8.7 & 14.7 & 10.5 & 42.0 & 40.0 \\
\hline GLY & $\mathrm{g} / \mathrm{kg}$ & 6.5 & 17.4 & 10.6 & 63.6 & 63.9 \\
\hline ALA & $\mathrm{g} / \mathrm{kg}$ & 9.4 & 15.8 & 11.6 & 42.3 & 39.7 \\
\hline VAL & $\mathrm{g} / \mathrm{kg}$ & 10.3 & 13.8 & 11.5 & 28.1 & 26.6 \\
\hline ILE & $\mathrm{g} / \mathrm{kg}$ & 8.2 & 10.6 & 9.1 & 20.0 & 18.8 \\
\hline LEU & $\mathrm{g} / \mathrm{kg}$ & 14.6 & 19.4 & 16.4 & 38.9 & 38.7 \\
\hline TYR & $\mathrm{g} / \mathrm{kg}$ & 6.5 & 8.5 & 7.3 & 16.5 & 16.3 \\
\hline PHE & $\mathrm{g} / \mathrm{kg}$ & 9.5 & 11.7 & 10.2 & 21.5 & 19.5 \\
\hline HIS & $\mathrm{g} / \mathrm{kg}$ & 5.2 & 7.8 & 5.7 & 16.0 & 13.9 \\
\hline LYS & $\mathrm{g} / \mathrm{kg}$ & 9.9 & 14.8 & 11.6 & 33.9 & 30.2 \\
\hline ARG & $\mathrm{g} / \mathrm{kg}$ & 9.9 & 15.0 & 12.1 & 37.1 & 40.8 \\
\hline CYS & $\mathrm{g} / \mathrm{kg}$ & 3.6 & 3.6 & 3.8 & 3.4 & 4.8 \\
\hline MET & $\mathrm{g} / \mathrm{kg}$ & 4.8 & 5.8 & 5.2 & 9.8 & 8.1 \\
\hline Sum AA & $\mathrm{g} / \mathrm{kg}$ & 170.9 & 241.2 & 196.6 & 536.3 & 529.2 \\
\hline
\end{tabular}



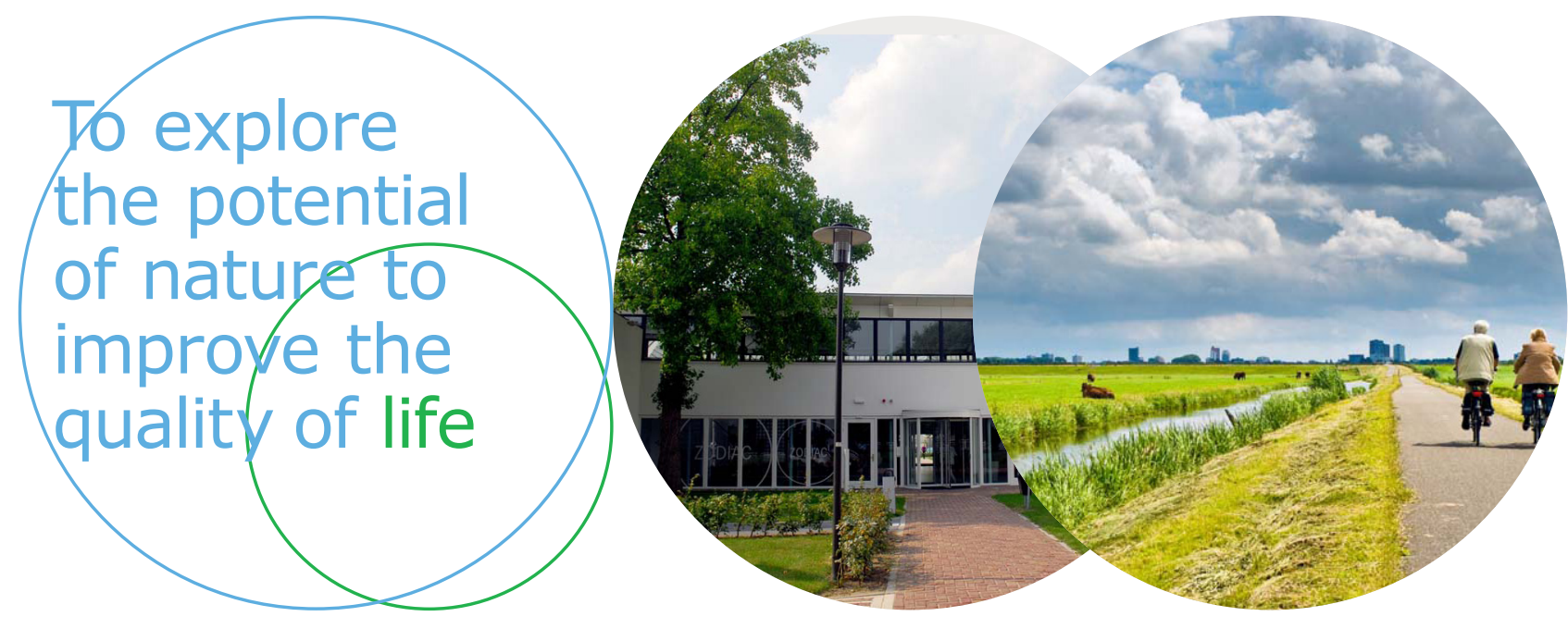

Wageningen Livestock Research P.O. Box 338

6700 AH Wageningen

The Netherlands

$\mathrm{T}+31(0) 317483953$

E info.livestockresearch@wur.nl

www.wur.nl/livestock-research

Wageningen Livestock Research creates science based solutions for a sustainable and profitable livestock sector. Together with our clients, we integrate scientific knowledge and practical experience to develop livestock concepts for future generations.

Wageningen Livestock Research is part of Wageningen University \& Research. Together we work on the mission: 'To explore the potential of nature to improve the quality of life'. A staff of 6,500 and 10,000 students from over 100 countries are working worldwide in the domain of healthy food and living environment for governments and the business community-at-large. The strength of Wageningen University \& Research lies in its ability to join the forces of specialised research institutes and the university. It also lies in the combined efforts of the various fields of natural and social sciences. This union of expertise leads to scientific breakthroughs that can quickly be put into practice and be incorporated into education. This is the Wageningen Approach. 